\title{
THE LONG-RUN ENVIRONMENTAL EFFECT OF AQUACULTURE AND FOOD TRADE IN EGYPT
}

\author{
Paul Adjei KWAKWA*I (D), Hamdiyah ALHASSAN ${ }^{2}$ (D), William ADZAWLA ${ }^{2,3}$ (iD)
}

\author{
Address: \\ ${ }^{1}$ Presbyterian University College Ghana, School of Business and Economics, Abetifi-Kwahu, Eastern Region, Ghana \\ ${ }^{2}$ University for Development Studies, Department of Agricultural and Resource Economics, Tamale, Ghana \\ ${ }^{3}$ University of Cheikh Anta Diop, West African Science Service Centre on Climate Change and Adapted Land Use \\ (WASCAL), Climate Change Economics, Dakar, Senegal \\ * Corresponding author e-mail: Pauladkwa@gmail.com
}

\begin{abstract}
This research analyses the effects of aquaculture and food trade on the environmental quality in Egypt within the Environmental Kuznets Curve (EKC) Hypothesis. Using an annual time series data from 1971-2014 and employing the fully modified ordinary least squares and the Autoregressive distributed lag techniques, the study finds that the EKC hypothesis holds for carbon dioxide emission and economic growth while there is a U-shape relationship between deforestation and economic growth. Also, livestock production increases carbon dioxide emission and deforestation; urbanization reduces carbon emission and cereal production reduces carbon emission but increases deforestation. Aquaculture has a positive effect on carbon emission but reduces deforestation and food import is seen to reduce carbon emission. These findings were confirmed by results from variance decomposition effect and impulse response analyses. The outcome implies that addressing environmental degradation through these variables cannot be a 'one-size fit all' approach. Instead, the approach must be considered based on the primary environmental cost a particular policy seeks to address. Among others, it is recommended that there is the need for Egyptian government to adopt comparative and/or competitive advantage food trade policies in order to solidify the carbon reducing effect of food import.
\end{abstract}

Keywords: Aquaculture; Carbon dioxide; Deforestation; Environmental quality; Food trade JEL: F18; F64; O13; O44; P18; Q22; Q53

\section{INTRODUCTION}

Meeting food security has been on the radar of many international organizations such as Food and Agricultural Organization (FAO). This objective was also reflected in the Millennium Development Goals (MDGs) that targeted a reduction of proportion of individuals suffering from hunger in the period between 1990 and 2015 by half. Transiting from the MDGs, the world leaders set out seventeen Sustainable Development Goals (SGDs) of which the second goal is to eliminate hunger by 2030 . Achieving this goal is crucial since it is directly or indirectly linked with other goals such as goal one (eliminating poverty) and goal three (good health and wellbeing). Fact is, the role of agriculture in the developmental process of economies cannot be overemphasized. The agricultural sector in many developing countries offers job opportunities to a large proportion of the labour force and it is also a major source of foreign exchange revenue. The expectation therefore is to achieve a vibrant and expanding agricultural sector.

The expansion of the agricultural sector may have implications on countries' effort to meet SDGs six (clean water and sanitation), eleven (sustainable cities and communities), twelve (responsible consumption and production) and thirteen (climate action). Thus, although agricultural development is crucial for achieving the growth and developmental needs of countries, it may have some adverse effects on environmental sustainability. For instance, clearing of forest for agriculture increases carbon dioxide emission and reduces carbon sequestration (Maraseni and Cockfield, 2011). According to FAO (2019), forest cover helps to store more than 650 billion tons of carbon dioxide. The reasoning from this is that when the forest covers are removed, emission of carbon dioxide into the atmosphere increases. As a result, FAO (2014) has revealed that over the past 50 years, global greenhouse gas (GHG) emissions associated with agriculture, fishery and forestry activities has doubled and it is expected to see another $30 \%$ increment in the near future. Between 2001 and 2011, the global carbon dioxide emissions from livestock and crop activities increased by $14 \%$ from 4.7 billion tons to more than 5.3 billion tons (FAO, 2014).

Literature (US EPA, 2006; FAO, 2006; and Bellarby et al., 2008) cited by Desjardins et al. (2015) also indicate that direct farming activities accounts for 13$15 \%$ of global emissions and if combined with land use change, leads to about $18-32 \%$ of global emissions. Since environmental degradation, generally, poses great threat to sustainable development, the deforestation effect of agriculture and the associated carbon dioxide emission cannot be overlooked. Efforts must be made to ensure major reductions in the agricultural carbon footprints. 
Owing to the importance of the agricultural sector in every economy, one cannot recommend efforts to stall the growth of the sector. Rather, policymakers need to promote environmentally friendly agricultural sector. Accordingly, researchers have recognized the need to estimate the environmental impact associated with the expansion of the agricultural sector as a way of determining whether countries' agricultural practices are environmentally efficient or not in order to inform policymaking. This paper therefore aimed at estimating the environment cost of agricultural indicators using the Egyptian data.

Although there is an increasing empirical studies including Kwakwa et al. (2014), Parajuli et al. (2019), Asumadu-Sarkodie and Owusu (2016; 2017) that have focused on the subject matter there is still the need for further studies to unearth location specific costs and bridge the gaps in these previous studies. Empirically, some past studies examined the effect of aggregate agricultural sector on carbon emission (Kwakwa et al., 2014; Rafiq et al., 2015) while others focused on the effect of some agricultural indicators such as crop production and livestock production (Asumadu-Sarkodie and Owusu, 2017) and emission effect of agricultural land usage (Parajuli et al., 2019). So far, the effect of aquaculture and food trade has not received much empirical attention. Meanwhile, Robb et al. (2017) have pointed out a high associated energy demand for preparing fish feed and in the transportation of the processed feed. The increasing use of energy may eventually exert pressure on the environment through the depletion of non-renewable energy source and also carbon emission. The need to prepare the feed also requires more forest land is cleared. This should raise concern for all to understand the environmental costs associated with the aquaculture sector. Like aquaculture, scholars have indicated that trade openness negatively affects carbon doxide emission through high energy consumption used for manufacturing, processing and transportation of goods (Sadorsky, 2011; Kwakwa et al., 2018). It also affects the environment when there is weak environmental regulation instituted by the government with the aim of attracting foreign direct investment (Kwakwa and Alhassan, 2018). Similarly, the effect of food trade on environmental degradation may be witnessed through the processing of agricultural products into finished good and transportation of food to and from the ports. In the light of this, the current study employs econometric tools to investigate the effects of aquaculture and food trade on environmental degradation (carbon dioxide emission and deforestation) in Egypt.

Egypt offers a perfect candidate for the study. The agriculture sector continues to play a major role in the socioeconomic development of the country. Although aquaculture in Egypt can be traced back as far as the 2500 B.C, modern aquaculture began around the mid-1930 and it has intensified since the last two decades. The subsector has, thus, grown to offer significant contributions to the Egyptian economy. For instance, available records show that 65 percent of the country's total fish production is from its aquaculture and it employs close to 70,000 people in the country (FAO, 2019). General Authority for Fish Resources Development has revealed that the total aquaculture production in 2009 was valued at about US\$ 1,354.65 million (FAO, 2013). The production level of fish from aquaculture in Egypt makes it the $9^{\text {th }}$ top fish producing country in the world and the first in Africa (Soliman and Yacout, 2016). The nature of aquaculture in the country has seen a shift from traditional family-run business into a modern industry whose effect has been the practice of semi-intensive and intensive fish farming (FAO 2019). On trade, food and agricultural products constitute about $40 \%$ of the country's imports. Egypt's importation of dairy products amounts to about US\$ 1 billion per year and it remains one of the largest importers of wheat, sugar, and oils in the world (Worldexgroup, 2018).

The country has its own environmental challenges. Although the country's carbon dioxide emission is comparatively low it has seen an upward trend over the years from $125,393.1 \mathrm{kt}$ in 2004 to $206,734.5 \mathrm{kt}$ in 2014 (WDI, 2019). Again, the well-known energy challenge that faces Egypt (Kwakwa, 2017) has not been resolved yet. When it comes to vegetation loss, Egypt lost 1,300 ha. of its forest cover between 1990 and 2010 (Mongabay, n.d). Despite the above facts, empirical investigation of the effect of food trade and aquaculture on the environmental quality in Egypt is rarely available. This paper therefore makes a number of contributions to the literature on environmental degradation. In the first place, this is the first paper to comprehensively examine the environmental degradation effect of human induce activities focusing on carbon dioxide emission and deforestation in a single study. Secondly, the study is the first to econometrically estimate the carbon emission of aquaculture on the environment. Third, the extant studies on the effect of trade on environmental degradation have not yet provided much evidence on food trade specifically. Fourth, the paper contributes to the limited studies that have examined the drivers of environmental degradation in Egypt since with the exception of Abdou and Atya (2013) which focused mainly on Egypt, the other works like Omri (2013), Owoye and Onafowora (2013) and Balogh and Jambor (2017) did a panel study for countries that included Egypt without a detail analysis for the Egyptian economy.

\section{LITERATURE REVIEW}

In this section a review of the theoretical and empirical works related to environmental degradation are discussed.

\section{Effect of income on environmental degradation}

One of the key theories to explain the human induced environmental effect is the Environment Kuznets Curve (EKC) hypothesis (Dinda, 2004; Shahbaz and Sinha, 2019). The theory is used to examine the effect of income on environmental degradation (Grossman and Krueger, 1995). According to the EKC hypothesis, an initial increase in economic growth would lead to environmental degradation to a point, beyond where environmental degradation declines. Thus, the relationship between income and environmental degradation exhibits an inverted U-shape. The reasons underpinning this argument is that economic growth has a scale effect (i.e. at the initial 
stage of development where the use of conventional and inefficient technology in production increases carbon dioxide emissions and degrades the environment); composition effect (i.e. transition of the economy to industrial and then to service sector, encourage investment in sector that degrade less) and technical effects (i.e final stage where higher economic growth reduce environmental degradation through the adoption of environmental friendly policies and use of eco-friendly technology in production) (Grossman and Krueger, 1995; Panayotou, 1997 and Stern, 2003). Empirical studies to verify the EKC hypothesis have yielded conflicting results. Scholars such as Mahmood et al. (2019), Shahbaz et al. (2012); Tiwari et al. (2013); Alam et al. (2016); Al-Mulali and Ozturk (2016); Kwakwa and Adu (2016); Aboagye (2017); Shahbaz et al. (2018); Sinha and Shahbaz (2018) found support for the EKC hypothesis. However, studies by Onafowora and Owoye (2014); Nassani et al. (2017); Dogan and Ozturk (2017); Sinha et al. (2017) and Balsalobre-Lorente et al. (2018) failed to confirm the EKC hypothesis.

\section{Effect of urbanization on environmental degradation}

To avoid omission biased effect in the estimation process of testing for the EKC hypothesis, one variable that researchers include in the model is urbanization. The theoretical literature on urbanization- environmental nexus points to three main theories: ecological modernisation, urban transition and compact city theories (McGranahan et al., 2001; Poumanyvong and Kaneko, 2010). According to the ecological modernisation theory, urbanization plays an important role in the economic transformation of the sectoral structure from agricultural to industrial and then to the service sector, which has the potential to reduce the environmental degrading effect of economic growth (Mol and Spaargaren, 2000). The theory of urban transition shows the link between wealth and environmental issues in urban cities. On one hand, it argues that, as cities move from low to middle-income stage of development, concentration of people, production and consumption increases industrial pollution. Then as urban cities transit into higher-stage of development, environmental regulations, technological innovation and shift from industrial to service sector reduces pollution. By way of contrast, a higher-stage of development at the urban centers may also increase residents' income and consumption of energy intensive products which may have environmental degrading effects (McGranahan $\boldsymbol{e t}$ al., 2001). The compact city theory concentrates on the positive effect of increased urbanization. It posits that, compaction of urban cities through the development of existing urban areas rather than in suburbs, promote economies of scale for public infrastructure such as public transportation and electricity production which lowers environmental degradation (Burton, 2000). The above theories imply that the effect of urbanization on the quality of the environment is not straightforward and this has reflected in mixed results from empirical studies. For instance, Poumanyvong and Kaneko (2010) reported that urbanization increases $\mathrm{CO}_{2}$ emissions of 99 countries. Kwakwa and Adu (2016) recorded a positive effect of urbanization on carbon dioxide emissions in sub-Saharan
African countries. In their studies, Martinez-Zarzoso and Maruotti (2011) and Shahbaz et al. (2015) all found an inverted U-shaped relationship between urbanization and $\mathrm{CO}_{2}$ emissions for a panel of 69 countries and Malaysia respectively. Hassan, (2016) and Adom (2017) obtained a positive relationship between urbanization and environmental degradation. Kwakwa et al. (2018) also found that urbanization increases fossil fuel consumption in Ghana, Kenya and South Africa. De Fries et al., (2010) found there is a positive association between urbanization and the rate of deforestation.

\section{Effect of agriculture on environmental degradation}

In recent times the effect of agricultural activities on the quality of the environment has attracted much attention. The effect of agricultural growth on the environmental degradation is theoretically ambiguous. Agricultural growth may exert scale and technical effects on the environment. Different reasons have been attributed to the scale effect of agricultural production on the environment. First, conversion of forest to farmlands to meet food and nutritional needs of the ever-growing population may lead to deforestation and that may also lead to higher carbon dioxide emission (Stern, 2006; Baccini et al. 2012). Second, adoption of fuel-driven agricultural machine and irrigation increase consumption of fossil fuel which emits carbon dioxide (Arapatsakos and Gemtos, 2008). Lastly, Pellerin et al. (2013) argue that increase use of nitrogenrich fertilizers is reported to increase Greenhouse gas (GHG) emissions. Contrarily, Valin et al. (2013) and Panhwar (2004) posit that adoption of modern and sustainable agricultural practices such as sustainable land intensification, solar tube wells for irrigation and organic farming reduce fuel consumption, increase production and help reduce environmental degradation. Like other researchers, FAO (2017) explained that the effect of aquaculture on environmental quality is through the process of preparing and transporting fish feed since these require significant amount of energy. The increasing use of energy may eventually exert pressure on the environment through the depletion of non-renewable energy source and also carbon dioxide emission.

Empirically, Ismael et al. (2018) use the variance error decompositions to show that fertilizers, crop and livestock production, land under cereal production, water access and agricultural value addition affect the quality of the environment in Pakistan. Waheed et al. (2017) found that agricultural production increases $\mathrm{CO}_{2}$ emission whiles forest planting reduces $\mathrm{CO}_{2}$ emission. Using ARDL method, Asumadu-Sarkodie and Owusu (2017) found in the short-run that, increase in copra and green coffee production increases carbon dioxide emissions whiles increase in millet and sorghum production decrease carbon dioxide emissions. In a similar study, Codjoe and Dzanku (2009) employed the Dynamic Least Squares technique and found conversion of forestland to crop farm as a contributor to deforestation in Ghana. Kwakwa et al. (2014) also found agricultural growth increases the longrun carbon emission in Ghana. Faria de Almeida (2013) found among other things that cattle rearing, soya bean cultivation increases deforestation in the Amazon region. The empirical findings have indicated a mixed effect of 
agriculture on environmental quality with little emphasis on the effect from aquaculture.

\section{Effect of trade on environmental degradation}

In the economic literature on trade-environment nexus, different channels, of conflicting directions, through which trade openness impacts the environment have been discussed. On one hand, trade openness is argued to have an environmental degrading effect and this is called the pollution-haven hypothesis (Neumayer, 2004). The hypothesis argues that, pollution-intensive industries (re)locate their environmental degrading activities from countries with strict regulations (or standards) to economies with weaker environmental regulations (or standards) and poor enforcement, polluting those countries (mostly developing countries). Sadorsky (2011) and Kwakwa et al. (2018) have argued that trade openness increases carbon emission through high energy consumption used for manufacturing and transportation of goods. Contrary to the above, it has been argued that trade increases real income which enables individual to demand for clean environment through strict environmental regulations, production and consumption of clean technology thereby improving the quality of the environment (Liddle 2001).

Harris (2004) explained that trade openness encourages the transfer of cleaner and eco-friendly technology among trading countries. Although the reverse is also valid, Robalino and Herrera (2009) pinpointed that trade liberalization affects deforestation through prices of natural resources. They indicate that a lower price of local natural resource compared to resources in the rest of the world would increase demand for export and hence an increase in the extraction rate; the opposite is true. Halicioglu (2008) observed that trade increases carbon dioxide emission for the Turkish economy; Pié $\boldsymbol{e t}$ al. (2018) found among EU countries imports increase carbon dioxide emissions while higher export reduces carbon emissions; El-Aasar and Hanafy (2018) found that trade openness has no significant effect on GHG emissions in Egypt; and regarding fossil fuel consumption Kwakwa et al. (2018) found trade increases fossil fuel consumption for Ghana but reduces for Kenya and South Africa. Tsurumi and Managi (2014) found that trade openness increase deforestation for non-OECD countries but decreases it for OECD countries. In addition, Faria de Almeida (2013) found that trade openness increases deforestation.

Among studies that have examined the environmental effect of trade openness, the effect of food trade on environmental degradation has been ignored to a large extent. However, the effect of food trade on environmental degradation may be witnessed through the processing of agricultural products into finished goods and transportation of food to and from the ports. In addition, it is seen that studies which analyse the environmental degrading effect of human activities in Egypt is quite limited and these must be addressed.

\section{DATA AND METHODS}

Theoretically, within the EKC hypothesis framework, the relationship between economic growth and environmental degradation is expressed as the Eq. 1.

$E N V D_{t}=G D P_{t} * G D P_{t}^{2} * \varepsilon_{t}$

where $E N V D$ is environmental degradation, $t$ represents time, $\varepsilon$ is the stochastic error term which captures unobserved factors that influence environmental degradation and * represents the multiplication sign. GDP is income and $G D P^{2}$ is income squared to reflect a quadratic relationship.

Empirically, different indicators have been used to represent environmental degradation. Following Aboagye (2017) and Adom et al. (2018), carbon emission and deforestation were used as indicators for environmental degradation. The thinking behind the adoption of these indicators are, conversion of forestland to farmland as well as the excessive felling of trees and burning of forestland may cause deforestation; which in turn increases $\mathrm{CO}_{2}$ emissions and degrades the environment (Baccini et al., 2012).

Urbanization is well-known to have significant impact on the environment but its effect is mixed. Rapid rate of urbanization may increase production and consumption which put pressure on resources (Shahbaz et al., 2015; Kwakwa et al., 2018); or urbanization may promote economies of scale as it reduces the demand for urban infrastructure such as transport system, thus reduction in energy consumption with associated increase in environmental quality (Elliot and Clement 2014). As argued in the literature, trade openness is used to capture scale, as well as technique effects (Erickson et al., 2013; Kwakwa et al., 2018). These effects have opposite signs: while the environment deteriorates with growth in trade openness (i.e scale effect), the demand for high environmental quality and the transfer and adoption of cleaner production technology are expected to increase with trade (i.e technique effect). Agriculture is one of the major sectors for Egypt's economy and employs most of the rural population (ADBG, 2018). In this light, food trade and aquaculture are included in the model. Following Ismael et al., (2018) and Asumadu-Sarkodie and Owusu (2016), livestock and cereal production were used as proxy for other agricultural production. This is in part motivated by the argument that agriculture is a victim and emitter of $\mathrm{CO}_{2}$ and there is the need for policymakers to promote environmentally friendly agricultural sector.

Given these relationships, the study proceeded to expand equation 1 to capture the effects of crop production, livestock production, aquaculture and food trade on environmental degradation (carbon dioxide emission and deforestation) (Eq.2). $E N V D_{i t}=G D P_{t} * G D P_{t}^{2} * U R B_{t} * e^{\text {LIVESTOK }_{t}} * A C Q_{t} *$
$C E R_{t} * F I M P_{t} * F E X P_{t} * e^{\varepsilon_{t}}$ 
Where:

$i \quad(=1$ and 2) represents the two indicators for environmental degradation: carbon dioxide emission and deforestation. Also, URB, LIVESTOK, ACQ, CER, FIMP and FEXP respectively denote urbanization, livestock production, aquaculture, cereal production, food import and food export. $G D P$ and $G D P_{t}^{2}$ remains as explained earlier. Assuming a Cobb-Douglas production function with output generated measured as carbon dioxide emissions $\left(\mathrm{CO}_{2}\right)$ and deforestation (DEF), the predictors of environmental degradation as inputs, the production function is presented as the Eq. 3 .

$$
\begin{aligned}
& E N V D_{i t}=A * G D P_{t}^{\beta_{1 i}} * G D P_{t}^{2^{\beta_{2} i}} * U R B_{t}^{\gamma i} * \\
& e^{L I V E S T O K_{t}^{\delta i}} * A C Q_{t}^{\vartheta i} * C E R_{t}^{\rho i} * F I M P_{t}^{\pi i} * F E X P_{t}^{\varphi i} * \\
& e^{\varepsilon_{i t}}
\end{aligned}
$$

Where:

$A$ is the technological change. Taking a log transformation of equation (3) expanding equation (3) in terms of the two indicators for environmental degradation, gives Equations (4a) and (4b).

$$
\begin{aligned}
& L C O_{2 t}=a_{1}+\beta_{11} L G D P_{t}+\beta_{21} L G D P_{t}^{2}+\gamma_{11} L U R B_{t}+ \\
& \delta_{11} L I V E S T O K_{t}+\vartheta_{11} L A C Q_{t}+\rho_{11} L C E R_{t}+ \\
& \pi_{11} L F I M P_{t}+\varphi_{11} L F E X P+\varepsilon_{1 t}
\end{aligned}
$$

$L D E F_{t}=a_{2}+\beta_{12} L G D P_{t}+\beta_{22} L G D P_{t}^{2}+\gamma_{12} L U R B_{t}+$ $\delta_{12}$ LIVESTOK $_{t}+\vartheta_{12} L A C Q_{t}+\rho_{12} L C E R_{t}+$

$\pi_{12} L_{F I M P}+\varphi_{12} L F E X P+\varepsilon_{2 t}$

\section{Econometric method}

Generally, most time series data are non-stationary at level and as a result are not appropriate for regression estimation since they are likely to generate spurious results. Thus, in order to properly specify a model for estimation of equations (4a) and 4(b), it is important to conduct a unit root test to examine the stationarity situation of the variables. The Augmented Dickey-Fuller (ADF) and the Phillips-Perron(PP) tests developed by Dickey and Fuller (1979) and Phillips and Perron (1988) respectively were used to examine the stationarity property of the variables. The null hypothesis is that there are non-stationary variables (or unit root). To avoid having bias results from the $\mathrm{ADF}$ and PP tests in the presence of structural breaks that may be associated with the variables, a further investigation is done to check for the stationarity of the variables using the Zivot and Andrews (ZA) test which is more robust even in the presence of structural breaks.

The next step after the stationarity tests is to examine the existence of long-run relationship among the variables. Engel-Granger residual based test due Engle-Granger (1987), the Phillips-Ouliaris residual-based test by Phillips-Ouliaris (1990) and the robust Autoregressive distributed lag (ARDL) tests due Pesaran et al. (1996) and Pesaran (1997) were employed to examine if there exists a long-run relationship between the variables. All the tests assume a null hypothesis of no cointegration. After a confirmation of the existence of cointegration among the variables, the ARDL method by Pesaran et al. (1996) and
Pesaran (1997) and the Fully Modified Ordinary Least Square (FMOLS) developed by Phillips and Hansen (1990) were applied to examine the long-run relationship between the dependents and independent variables for equations (4a) and (4b). While the ARDL estimator is more robust when doing cointegration analysis for small samples like this, the FMOLS is robust to dealing with the problem of endogeneity and serial correlation. Thus, these two estimators were to corroborate each other.

The study also conducted impulse response and variance decomposition analysis (Amisano and Giannini, 1997; Lütkepohl, 2010). The impulse response analysis was done to examine how the dependent variables responds to shocks in each independent variable and the duration of the effect of the shock, whiles the variance decomposition analysis was used to examine the pattern of contribution each factor would make due to a shock in the dependent variables (i.e carbon dioxide emission and deforestation) over time.

\section{Data source and descriptions}

This study used annual time-series data covering the period 1971-2014 accessed from World Development Indicators (WDI, 2019). The choice of this period was based on data availability. Indicators of environmental degradation used were: carbon dioxide $\left(\mathrm{CO}_{2}\right)$ measured by carbon dioxide emissions (metric tons per capita); and deforestation measured by land under cereal production in hectares. GDP per capita is used to measured income while urbanization is proxied by total urban population. Furthermore, aquaculture is measured by aquaculture production in metric tons, livestock is denoted by livestock production index and cereal production is measured in metric tons. Food trade is measured as food import and export.

\section{RESULTS AND DISCUSSION}

This section provides the empirical findings emanating from the study. It includes hypothesis testing results on stationarity, ARDL and FMOLS results, and results on impulse response function and variance decomposition. Detailed discussion on each of these results are also provided under the section.

\section{Unit root test and cointegration results}

The results of the unit root tests are reported in Tables 1 and 2. Table 1 provides results for the ADF and PP tests while Table 2 shows results for the Zivot-Andrews test. The ADF and PP tests indicate that food import is stationary at levels while the remaining are stationary at first difference (Table 1). The Zivot-Andrews test results also confirm that all the variables except the square of GDP, urbanization, aquaculture and food import become stationary after first difference despite the presence of structural break (Table 2) giving us a mixture of $\mathrm{I}(0)$ and I(1) variables. The implication is that, the variance and covariance of all the variables remain unchanged over time and hence, appropriate for regression analysis. 
Table 1: Unit root test results

\begin{tabular}{|c|c|c|c|c|}
\hline \multirow[b]{3}{*}{ Series } & \multicolumn{2}{|c|}{ Trend \& Intercept } & \multicolumn{2}{|l|}{ Trend \& Intercept } \\
\hline & PP & $\mathrm{ADF}$ & PP & $\mathrm{ADF}$ \\
\hline & At levels & & At first difference & \\
\hline$\overline{\text { LGDP }}$ & -2.3491 & -0.6804 & $-5.2309 * * *$ & $-4.2729 * * *$ \\
\hline $\mathrm{LGDP}^{2}$ & -2.4117 & -0.7132 & $-5.1797 * * *$ & $-4.2386 * * *$ \\
\hline LURB & -2.9820 & -1.4974 & $-3.9535 * *$ & -2.4348 \\
\hline LIVESTOK & -2.3454 & -2.3405 & $-5.8759 * * *$ & $-5.9044 * * *$ \\
\hline LACQ & -2.4332 & -2.1293 & $-4.9645 * * *$ & $-4.9951 * * *$ \\
\hline LFIMP & $-4.0984 * *$ & $-3.7012 * *$ & & \\
\hline LFEXP & -2.0890 & -2.0890 & $-5.8959 * * *$ & $-7.2431 * * *$ \\
\hline LCER & -6.6580 & -1.7534 & $-6.6583 * * *$ & $-6.6584 * * *$ \\
\hline $\mathrm{LCO}_{2}$ & -1.5052 & -1.7127 & $-7.7607 * * *$ & $-7.7746 * * *$ \\
\hline LDEF & -2.5272 & -2.5111 & $-7.4315 * * *$ & $-7.3774 * * *$ \\
\hline
\end{tabular}

Note: $* * *, * *$ and $*$ denotes $1 \%, 5 \%$ and $10 \%$ level of significance respectively

Table 2: Zivot Andrew unit root test

\begin{tabular}{|c|c|c|c|c|}
\hline \multirow[t]{2}{*}{ Series } & \multicolumn{2}{|l|}{ Levels } & \multicolumn{2}{|l|}{ First difference } \\
\hline & Trend & Intercept & Trend & Intercept \\
\hline$\overline{\text { LGDP }}$ & $-5.6150(1985)$ & $-4.2115(1980)$ & $-6.4329(1992) * *$ & $-6.8665(1986) * * *$ \\
\hline $\mathrm{LGDP}^{2}$ & $-5.4852(1985) * * *$ & $-4.4207(1980)$ & & $-6.6552(1986) * * *$ \\
\hline LURB & $-5.2158(1987)$ & $-5.3925(1979) * * *$ & $-3.6078(1987)^{* * *}$ & \\
\hline LIVESTOK & $-2.9686(2003)$ & $-3.4517(1985)$ & $-6.4439(2007)^{* *}$ & $-6.8243(1990) * *$ \\
\hline LACQ & 3.6942 (1994) & $-4.6823(1998) * * *$ & $-5.8598(1995)^{* * *}$ & \\
\hline LFIMP & $-5.0308(1995) * * *$ & $-5.5879(2005) * * *$ & & \\
\hline LFEXP & $-3.6130(1981)$ & $-4.6128(1979)$ & $-4.6965(1998) * *$ & $-4.9799(1993) * *$ \\
\hline LCER & $-2.5765(2003)$ & $-4.4933(1989)$ & $-7.4515(1991)^{* * *}$ & $-7.7896(1987)^{* * *}$ \\
\hline $\mathrm{LCO}_{2}$ & $-3.0477(1982)$ & $-2.4386(1979)$ & $-8.1156(2007) * * *$ & $-8.1964(1995) * * *$ \\
\hline LDEF & $3.0005(1984)$ & $-3.7401(1990)$ & $-7.4638(1991) * * *$ & $-8.2235(1987) * * *$ \\
\hline
\end{tabular}

Table 3: Cointegration test results

\begin{tabular}{|c|c|c|c|c|c|c|c|}
\hline & ARDL & & & Engel-Granger & & Phillips-Ouliari & \\
\hline Model & F-test stat. & $\mathrm{I}(0)$ & $\mathrm{I}(1)$ & tau-statistic & z-statistic & tau-statistic & z-statistic \\
\hline $\mathrm{CO}_{2}$ model & $4.2215 * * *$ & 2.79 & 4.1 & $-5.8626 * *$ & $-39.3552 * *$ & $-6.0060 * *$ & $-35.1101 *$ \\
\hline Deforestation model & $4.1797 * * *$ & 2.79 & 4.1 & $-5.8901 * *$ & $-39.5051 * *$ & $-5.9376 * *$ & -21.1996 \\
\hline
\end{tabular}

Note: $* * *, * *$ and $*$ denotes $1 \%, 5 \%$ and $10 \%$ level of significance respectively

In Table 3, the presence of co integration for each of the models is confirmed by the ARDL, Engel-Granger and the Phillips-Ouliaris tests. Thus, cointegration exists between carbon dioxide emission and the selected explanatory variables, and between deforestation and the selected explanatory variables. Therefore, income, livestock production, aquaculture, food import, food export, cereal production and urbanization can be described as the longrun forces of environmental degradation in Egypt.

\section{Long-run effects}

Table 4 shows the long-run estimates from ARDL and FMOLS methods. It displays the effects of the independent variables on carbon dioxide emission and deforestation. The result shows that GDP and its square have a significant effect on carbon emission. Also, urbanization, livestock production, aquaculture, food import, food export and cereal production have a significant effect on at least one of carbon emission and deforestation; although the direction of the effects differ for some variables.

\section{Carbon dioxide $\left(\mathrm{CO}_{2}\right)$ emission effect}

The positive significant effect of GDP shows that an increase in the current GDP levels lead to more carbon dioxide emission by the country. However, the square of GDP reduces the level of carbon emission. This confirms the existence of the EKC hypothesis. Thus, an initial increase in economic growth would lead to deterioration in environmental quality to a point, beyond which economic growth would be accompanied by an improvement in environmental quality. The findings in this study are consistent with the expectation that as GDP increases, the country would be able to invest in more emission reduction technologies that would lower $\mathrm{CO}_{2}$ emission. Previous empirical studies such as Kwakwa and Alhassan (2018), Mulali and Ozturk (2016), Aboagye (2017); Shahbaz et al. (2018); Sinha and Shahbaz (2018) confirmed the EKC hypothesis. In the case of Egypt, Mahmood et al. (2019) found that there is the presence of EKC and that the country is at the second stage of the curve, hence, they concluded that there is a clean economic growth in Egypt. Contrary, El-Aasar and Hanafy (2018) and Ibrahiem (2016) observed from 
Egypt that there is no evidence of EKC (inverted U-shape) in the short- or long-run.

The level of urbanization has a negative significant effect on carbon dioxide emission. This implies that an increase in the level of urbanization of the country leads to a decline in carbon dioxide emission. This supports the theory of urban transition that explains that as cities transit from middle to high levels of development, environmental regulations, technological innovation and a shift from industrial to service sector leads to a reduction in environmental pollution (McGranahan et al., 2001). Empirically, McGee and York (2018) observed that urbanization have an asymmetric effect on carbon dioxide emission and argued that, in addition to the level of urbanization, the pattern of rural-urban migration are important in explaining carbon emission. Evidently, Chen et al., (2019) estimated an inverted u-shape between urbanization and carbon emissions. Similarly, Ibrahiem (2016) estimated a negative relationship between population and carbon emission level in Egypt. Contrary to this study, Aye and Edoja (2017) and Zhang et al., (2015) estimated that irrespective of the duration (long-or short-run), urbanization increases carbon emission.

The effect of livestock production is positive and significant in explaining carbon dioxide emission. Thus, an increase in livestock production in the long-run would lead to a significant increase in carbon emission levels of the country. Although carbon dioxide is not a major greenhouse gas emitted in livestock production, its contribution to global warming remains important in climate discussions. Moran and Wall (2011) indicated that livestock production around the world is responsible for $18 \%$ greenhouse gas emissions (especially, methane gas). This percentage contribution is high; hence, its footprint can be highly detrimental to global environmental quality. The positive effect on carbon dioxide emission found for Egypt raises a concern for the country. Similarly, aquaculture has a positive significant effect on carbon emission. The implication is that an increase in aquaculture production will lead to an increase in carbon emission in the long-run. In the quest for higher aquaculture production, there is a high tendency of using high carbon emitting equipment and this would increase the carbon levels of the country. This effect is not only observed through forward linkages but also backward linkages where the demand for more aquaculture equipment would force manufacturing companies to increase their production. As explained by FAO (2017), the processes involved in the production and transportation of fish feeds may be environmentally unfriendly.

Food imports have a negative significant effect on carbon dioxide emission. Countries engage in the importation of goods and services to supplement domestic production shortfalls. Therefore, carbon emission levels through production activities would decline as a country tends to import more food demanded by the country granted that emissions from the transportation of these goods is at its minimum. This does not however provide an evidence to support the promotion of importation in the country since this may have a negative effect on the trade balance of the country. Consistently, Pié et al., (2018) found a negative significant effect of import on carbon emission. Although insignificant, El-Aasar and Hanafy (2018) and Ibrahiem (2016) found that there is a negative relationship between trade openness and carbon dioxide emissions in Egypt. It is not surprising that Mahmood $\boldsymbol{e t}$ al., (2019) suggested that the Egyptian government should further liberalize its foreign trade since this does not exert a significant effect on the country's environment. Contrary, Rafindadi (2016) have found import to increase carbon dioxide emission in his study. The finding shows that an increase in the cereal output leads to a reduction in carbon dioxide emission. The decrease in carbon emissions can be attributed to a long-term shift towards climate friendly production practices. Although insignificant, Rehman et al. (2019) also estimated a negative effect of total food grain on carbon dioxide emission both in the short and long-run. The finding of this study can be tired with the explanation of Valin $\boldsymbol{e t}$ al. (2013) and Panhwar (2004) that the adoption of modern and sustainable agricultural practices such as sustainable land intensification, efficient irrigation schemes and organic farming reduce fuel consumption, increase production and help reduce environmental degradation.

\section{Deforestation effect}

The long-run level of deforestation is significantly influenced by GDP and square of GDP, urbanization, livestock production, aquaculture, food export and cereal production. These effects are negative except for GDP squared and cereals. The positive significant effect of urbanization on deforestation in the FMOLS model implies that an increase in the level of urbanization of the country leads to an increase in deforestation. This is due to the high demand for land in urban areas and the high tendency of creating bare lands in the urban areas than in the rural areas. This shows that the growth in the Egyptian urban population over the years from a little over 15 million in 1971 to 25.4 million in 2001 and 36.9 million in 2011 has exerted pressure on the forest resources of the country. The finding corroborates the evidence provided by De Fries et al. (2010). It is also found that an increase in livestock production in the long-run would lead to a significant increase in deforestation of the country. The requirement for fodder and land for livestock production could elucidate the positive effect of livestock production on deforestation level in the country. Thus, the high requirement of natural resources in livestock production (Grossi et al., 2019) could explain the finding of high deforestation due to livestock production.

The positive and negative significance of GDP and GDP squared respectively on deforestation shows that there exists a U-shape relationship between economic growth and deforestation. It was expected that as the economy expands and income of households' increase, there would be high tendency towards the planting of trees, thereby, increasing the forest cover of the country at higher GDP. Although this U-shape relationship is contrary to the expectations of the research, it is plausible that at initial stages of economic growth, there are low technologies available for the fast exploitation of forest products and also, there is high regenerative capacity of forest at initial growth stage of the economy where the 
forest cover is high. As a developing country, it is expected that as technologies become available, there will be high tendency to exploit forest resources at a faster rate than the regenerative capacity of the forest and this would require significant income investment in afforestation products, which may not be a consideration in poor a country turning its economy into higher development. Admittedly, this result compares favourably with Galinato and Galinato (2012), Ewers (2006) and Couresma et al. (2017). Aquaculture has a negative significant effect on deforestation as well. The implication is that an increase in aquaculture production will lead to a decline in deforestation since through technology, households could possibly shift from large area-base production activities to the small area required for aquaculture.

Cereal production and consumption in Egypt remain significant. It is not surprising therefore that an increase in cereals output leads to an increase in deforestation. This increase in deforestation is because agriculture development in the country is largely due to land area expansion than yield improvement. The negative effect of food export implies that an increase in food export leads to a decline in deforestation. This could be because of the marginal share of food export in the country's total export. Egypt's main exports are gas and non-petroleum products such as gold and insulated wire. These products exert less impact on deforestation. Therefore, an increase in export would increase the income of the country which could be invested into afforestation programs that would reduce the level of deforestation in the country.

\section{Variance decomposition analysis}

The variance decomposition of the various independent variables in relation to the two dependent variables are presented in Tables 5 and 6 . The objective is to determine the pattern of contributions each factor would make in response to a shock in carbon dioxide emission and deforestation, over time. Thus, the result shows the percentage forecast error variance of each variable. In the first period, presumably the short run, results in Table 5 reveal that the independent variables exhibited weak influence on carbon emission since they do not contribute to the dependent variable. For instance, a change in carbon emission is $100 \%$ explained by itself in the first period. This influence decreases sharply as the other variables begin to have a strong influence on the dependent variables. Except for urbanization, all other variables exhibit a weak influence on carbon emission both in the short to the long-run. For instance, urbanization increases its contribution to carbon emission from $9.2 \%$ in the second period to about $20 \%$ in the fifth period and again declined to about $15 \%$ in the tenth period. Aquaculture also increases its influence from $1.79 \%$ in the third period, then gets to $5.07 \%$ in the $7^{\text {th }}$ period and finally to $8.56 \%$ in the $10^{\text {th }}$ period. It is also seen that the share of export is greater than import over the period. Urbanization, export and the square of GDP also exhibit a somehow moderate influence on deforestation. The general observation is that the effects of these variables increase from the short to the medium term, and gradually decline again in the long-run (Table 6).

Table 4: Long-run analysis from FMOLS results

\begin{tabular}{lrrrr}
\hline Variable & ARDL & \multicolumn{3}{c}{ FMOLS } \\
& Carbon emission & Deforestation & Carbon emission & Deforestation \\
\hline LGDP & $38.8917 * *$ & $-6.5844 * *$ & $13.7885 * * *$ & -1.8150 \\
& $(2.2325)$ & $(-2.7585)$ & $(4.4543)$ & $(-0.8184)$ \\
LGDP & $-0.8015 * *$ & $0.1344 * *$ & $-0.2644 * * *$ & 0.0320 \\
& $(-2.1830)$ & $(2.7162)$ & $(-4.1272)$ & $(-0.6972)$ \\
LURB & 1.8709 & -0.0864 & $-0.9990 *$ & $0.7636 * *$ \\
& $(1.2112)$ & $(-0.1928)$ & $(-1.9171)$ & $(2.0449)$ \\
LIVESTOK & $0.0239 * *$ & 0.0009 & $0.0069 * * *$ & $0.0028 * *$ \\
& $(2.1585)$ & $(0.7300)$ & $(4.0163)$ & $(2.2600)$ \\
LACQ & $0.2294 * *$ & $-0.0603 * * *$ & $0.1156 * * *$ & $-0.0748 * * *$ \\
& $(2.6775)$ & $(-2.9469)$ & $(4.0406)$ & $(-3.6489)$ \\
LFIMP & 0.1107 & 0.0199 & $-0.1311 * * *$ & -0.0240 \\
& $(0.8995)$ & $(0.5826)$ & $(-2.7912)$ & $(-0.7129)$ \\
LFEX & 0.0133 & $-0.0297 *$ & -0.0142 & -0.0023 \\
& $(0.3511)$ & $(-1.7413)$ & $(-0.5218)$ & $(-0.1187)$ \\
LCER & $-1.1306 * *$ & $0.3431 * * *$ & $-0.3255 * * *$ & $0.2772 * * *$ \\
& $(-2.4654)$ & $(4.6585)$ & $(-3.5773)$ & $(4.2515)$ \\
CONSTANT & $-488.2559 * *$ & $91.7912 * * *$ & $-157.9826 * * *$ & 23.3037 \\
& $(-2.3795)$ & $(3.0451)$ & $(-4.1268)$ & $(0.8494)$ \\
\hline
\end{tabular}

Note: $* * *, * *$ and $*$ indicates significance at $1 \%, 5 \%$ and $10 \%$, respectively; t-statistics in parenthesis 
Table 5: Variance decomposition analysis for carbon emission

\begin{tabular}{|c|c|c|c|c|c|c|c|c|c|c|}
\hline Period & S.E. & $\mathrm{LCO}_{2}$ & LGDP & LGDP $^{2}$ & LURB & LIVESTOK & LACQ & LFEX & LFIMP & LCER \\
\hline 1 & 0.052933 & 100.0000 & 0.000000 & 0.000000 & 0.000000 & 0.000000 & 0.000000 & 0.000000 & 0.000000 & 0.000000 \\
\hline 2 & 0.071815 & 63.71174 & 6.347745 & 14.06525 & 9.209495 & 1.465439 & 2.565952 & 1.953314 & 0.679580 & 0.001486 \\
\hline 3 & 0.086446 & 52.83003 & 5.040300 & 9.931120 & 21.92458 & 2.315675 & 1.799276 & 1.386703 & 0.477394 & 4.294919 \\
\hline 4 & 0.091973 & 49.95708 & 4.830996 & 8.775351 & 21.98019 & 2.726865 & 1.598149 & 5.881594 & 0.423228 & 3.826551 \\
\hline 5 & 0.096260 & 49.03182 & 4.433637 & 8.129249 & 20.27430 & 2.534305 & 2.638256 & 8.772629 & 0.689201 & 3.496598 \\
\hline 6 & 0.098895 & 49.53599 & 4.258544 & 7.796858 & 19.21091 & 2.437249 & 3.916192 & 8.763458 & 0.758079 & 3.322713 \\
\hline 7 & 0.104177 & 49.62247 & 3.882572 & 9.293473 & 17.49444 & 2.264445 & 5.074107 & 7.897384 & 0.979963 & 3.491144 \\
\hline 8 & 0.107779 & 49.51887 & 3.955687 & 9.281386 & 16.34618 & 3.135401 & 5.710573 & 7.477122 & 1.035241 & 3.539549 \\
\hline 9 & 0.110645 & 48.71446 & 3.890156 & 8.806864 & 15.59388 & 3.292798 & 7.181141 & 7.575227 & 1.071548 & 3.873922 \\
\hline 10 & 0.113525 & 47.12883 & 4.196312 & 8.397662 & 14.87841 & 3.298574 & 8.560290 & 8.364368 & 1.018119 & 4.157440 \\
\hline
\end{tabular}

Table 6: Variance decomposition analysis for deforestation

\begin{tabular}{|c|c|c|c|c|c|c|c|c|c|c|}
\hline Period & S.E. & LDEF & LGDP & LGDP $^{2}$ & LURB & LIVESTOK & LACQ & LFEX & LFIMP & LCER \\
\hline 1 & 0.033739 & 100.0000 & 0.000000 & 0.000000 & 0.000000 & 0.000000 & 0.000000 & 0.000000 & 0.000000 & 0.000000 \\
\hline 2 & 0.051648 & 47.95929 & 9.812484 & 18.25626 & 21.92786 & 0.284554 & 0.026831 & 0.366051 & 1.343986 & 0.022683 \\
\hline 3 & 0.059986 & 36.35791 & 17.69186 & 15.81261 & 18.10755 & 3.193289 & 0.359765 & 6.208422 & 1.717602 & 0.551000 \\
\hline 4 & 0.068437 & 28.88215 & 27.71748 & 12.24018 & 13.93238 & 6.188406 & 1.530455 & 7.446727 & 1.596358 & 0.465859 \\
\hline 5 & 0.072111 & 26.39834 & 32.52131 & 11.08934 & 14.03836 & 5.623751 & 1.669562 & 6.732847 & 1.490553 & 0.435937 \\
\hline 6 & 0.077065 & 23.11460 & 31.61733 & 10.76060 & 14.93872 & 6.450712 & 1.740668 & 8.969488 & 1.870356 & 0.537524 \\
\hline 7 & 0.081698 & 20.90222 & 31.23707 & 10.38509 & 13.29281 & 7.094331 & 2.218800 & 12.27557 & 1.923759 & 0.670359 \\
\hline 8 & 0.085916 & 18.90731 & 31.12872 & 10.96331 & 12.68785 & 6.744582 & 2.504569 & 14.43528 & 1.823973 & 0.804400 \\
\hline 9 & 0.087463 & 18.42211 & 31.35774 & 11.97367 & 12.24390 & 6.535215 & 2.744722 & 14.15555 & 1.768624 & 0.798468 \\
\hline 10 & 0.089153 & 17.81173 & 30.19553 & 14.16688 & 12.21817 & 6.410303 & 2.743359 & 13.96425 & 1.718213 & 0.771560 \\
\hline
\end{tabular}


Impulse response analysis

An impulse response analyses was performed to determine how the dependent variables responds to shocks in each independent variable and the duration of the effect of the shock. This is shown in Figures 1 and 2. The results show that carbon dioxide emission and deforestation fluctuate at different periods due to shocks imposed on each explanatory variable. Overall, carbon emission responded negatively to shocks in GDP, GDP squared, urbanization, livestock and import while it responded positively to shocks in aquaculture and exports. For instance, from Figure 1, carbon emission responded to shock in GDP by declining from about 0.05 in the first period to about 0.01 in the tenth period while it responded to shocks in export by declining to about -0.002 in year four and thereafter, increase to about 0.01 in the tenth year. The impulse response running from deforestation to livestock, export, import, cereal production and aquaculture as shown in Figure 2 is stable while that running to the square of GDP is initially positive up to the second year, declines to the fifth year and gradually begins to incline into the future. The implication is that deforestation vary less if there are compulsion in the independent variables over time. This is a laudable finding and suggests that Egypt's forest cover can be maintained for relatively long period even when there are shocks in the observed exogenous factors in the economy. In addition to the provision of sustainable forest products under stable deforestation, there is also a sustainable sink for carbon dioxide, thereby reducing the rate of increase in global warming.
Response of LCOPC to LCOPC

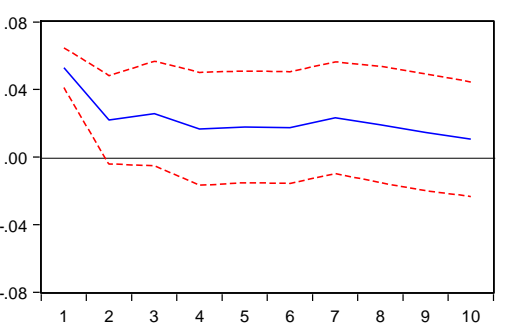

Response of LCOPC to LUB

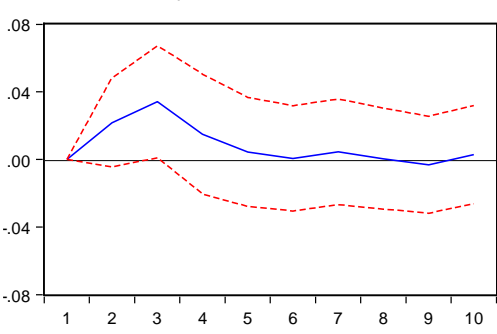

Response of LCOPC to LFEX

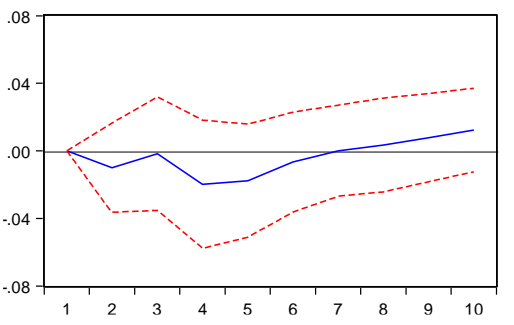

Response to Cholesky One S.D. Innovations \pm 2 S.E.

Response of LCOPC to LGPP

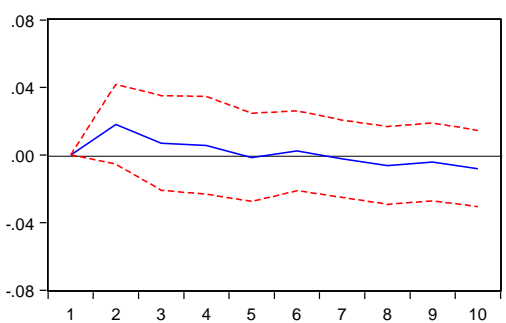

Response of LCOPC to LVSTCK

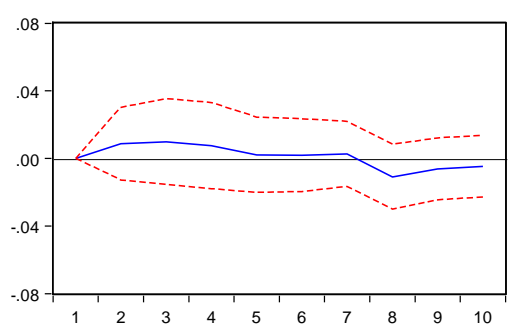

Response of LCOPC to LFIMP

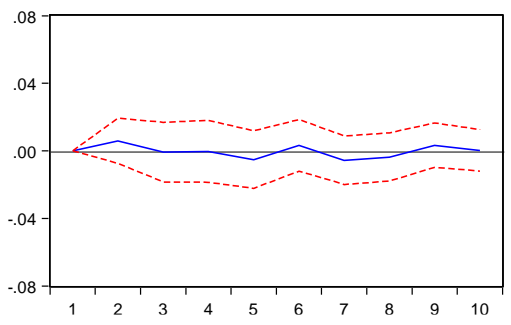

Response of LCOPC to LGDP2

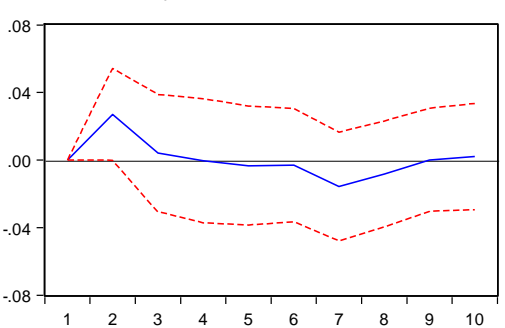

Response of LCOPC to LACQ

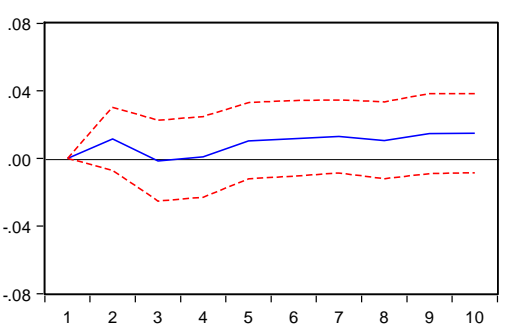

Response of LCOPC to LCER

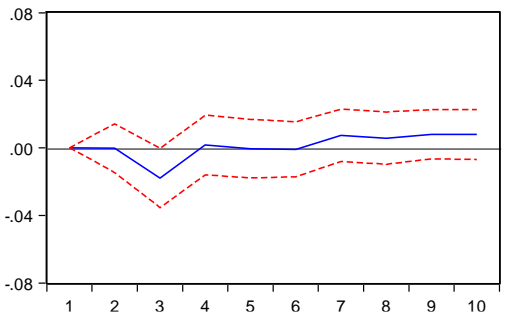

Figure 1: Impulse response function for carbon emission 
Response to Cholesky One S.D. Innovations \pm 2 S.E.

Response of LOLAND to LOLAND

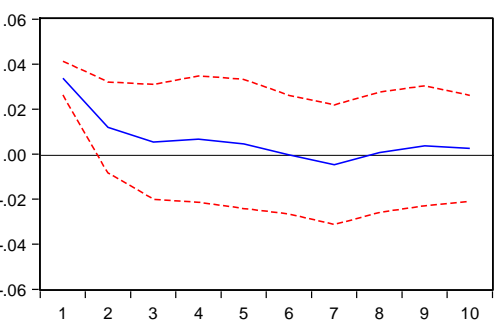

Response of LOLAND to LUB

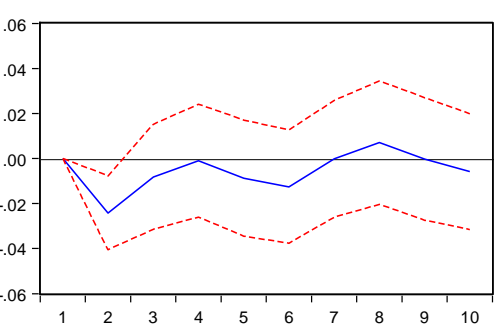

Response of LOLAND to LFEX

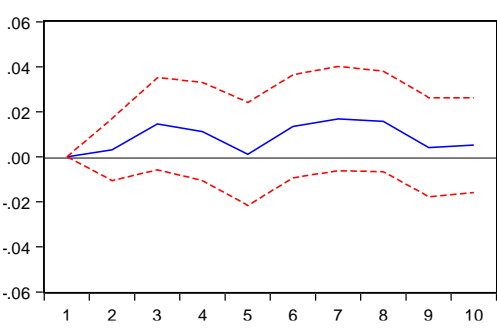

Response of LOLAND to LGPP

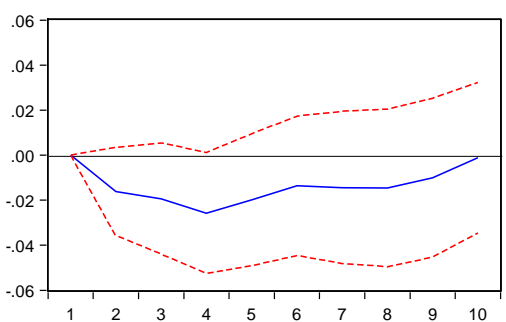

Response of LOLAND to LVSTCK

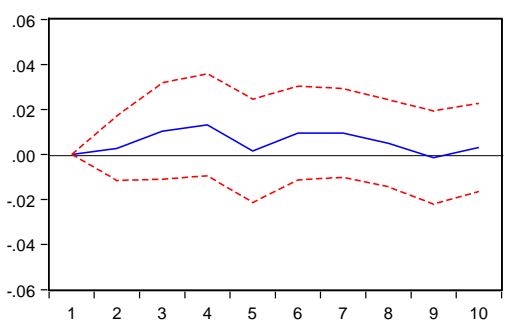

Response of LOLAND to LFIMP

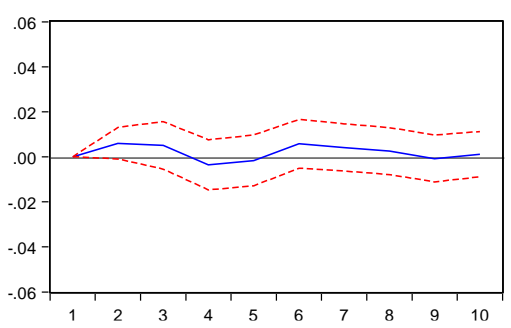

Response of LOLAND to LGDP2

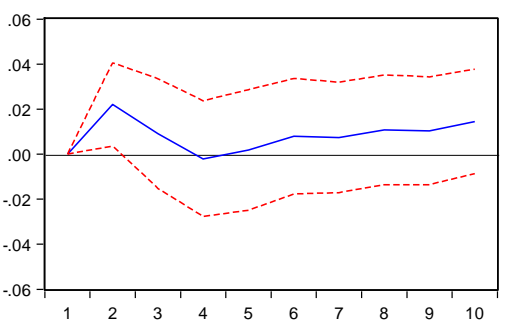

Response of LOLAND to LACQ

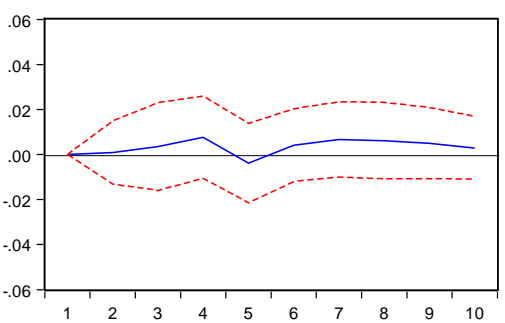

Response of LOLAND to LCER

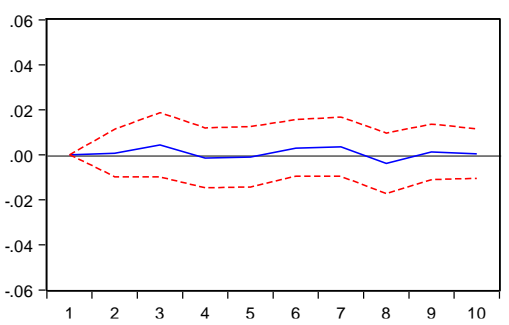

Figure 2: Impulse response function for deforestation

\section{CONCLUSIONS AND POLICY IMPLICATIONS}

Projected forecast of climate change and its impacts is driving scholars and policymakers into identifying how environmental quality can be improved and greenhouse gas emissions reduced alongside, an improvement in the economic performance of countries and wellbeing of citizens. This study analysed the long-run relationship between environmental quality and, aquaculture and food trade (after controlling for income, urbanization, livestock production and cereal production) within the Egyptian context. It was evident from this study that economic growth and carbon emission exhibited the EKC hypothesis that suggests that initial economic growth leads to an increase in carbon dioxide emission but further increase in economic growth leads to an improvement in environmental quality through a decline in carbon dioxide emission. In addition, it was found that urbanization, food import and cereal production leads to a reduction in carbon emission while livestock and aquaculture production leads to an increase in carbon emission in the long-run. While cereal production leads to a significant increase in deforestation, an increase in aquaculture production and food export leads to a decline in deforestation. There is also a significant U-shape relationship between economic growth and deforestation, a result that require further analysis. Conclusively, aquaculture had mixed effects on each of the environmental variables; it increases carbon dioxide emission and decreases deforestation. While food export reduces deforestation, food import was found to reduce carbon emission. Therefore, addressing climate change and environmental degradation through these variables cannot be a 'one-size fit all' approach. Instead, the approach must be considered based on the primary environmental cost a particularly policy seeks to address.

These findings have raised a number of policy concerns. For instance, it was evident from the study that effective food trade policies are important to regulate carbon emission in Egypt. To strengthen the effect of food trade on carbon emission and deforestation, there is the need to adopt comparative and/or competitive advantage food trade policies. Livestock and aquaculture production policies should be redesigned to ensure that their production does not foster increased carbon emission as estimated in this study. Cereal production should be promoted since this does not only reduce carbon emission but also, a way of achieving food sufficiency in the country. Nonetheless, sustainable production practices such as climate smart agriculture and intensified land cultivation that require less deforestation is required in promoting cereal production. It is also important to ensure that the intensity of aquaculture activities in Egypt becomes environmentally friendly. Thus, technologies for aquaculture development need a critical assessment to ensure that the benefit accrued to the nation through a reduction in deforestation can also be translated to a 
reduction in carbon emission. Overall, sustainable low carbon economic development agenda should not be over looked by policymakers in Egypt.

\section{REFERENCES}

ABOAGYE, S. (2017). Economic expansion and environmental sustainability nexus in Ghana. Afr Dev Rev 29: $155-168$.

ABDOU, D. M. S., \& ATYA, E. M. (2013). Investigating the energy-environmental Kuznets curve: evidence from Egypt. International Journal of Green Economics, 7(2), 103-115.

ADBG. African Development Bank Group (2018). Country results brief, Egypt. https://www.afdb.org/fileadmin/uploads/afdb/Documents /Generic-Documents/CRB Egypt 2018 En web.pdf

(Accessed on December 2, 2019)

ADOM, P.K., KWAKWA, P. K, \& AMANKWAA, A. (2018). The long-run effects of economic, demographic, and political indices on actual and potential $\mathrm{CO}_{2}$ emissions. Journal of Environmental Management, 218, 516-526.DOI:

https://doi.org/10.1016/j.jenvman.2018.04.090

ALAM, M. M., MURAD, M. W., NOMAN, A. H. M., \& OZTURK, I. (2016). Relationships among carbon emissions, economic growth, energy consumption and population growth: Testing Environmental Kuznets Curve hypothesis for Brazil, China, India and Indonesia. Ecological Indicators, 70, 466-479. DOI: https://doi.org/10.1016/j.ecolind.2016.06.043

AL-MULALI, U., \& OZTURK, I. (2016). The investigation of environmental Kuznets curve hypothesis in the advanced economies: the role of energy prices. Renew Sustain Energy Rev 54: 1622-31. https://doi.org/10.1016/j.rser.2015.10.131

AMISANO, G., \& GIANNINI, C. (1997). Impulse response analysis forecast error variance decomposition in SVAR modelling. In: Topics in Structural VAR Econometrics. Springer, Berlin, Heidelberg. DOI: https://doi.org/10.1007/978-3-642-60623-6_5 .

ARAPATSAKOS, C. I., \& GEMTOS, T. A. (2008) Tractor engine and gas emissions. WSEAS Trans Environ Dev, 4, 897-906.

ASUMADU-SARKODIE, S., \& OWUSU, P. A. (2016). The relationship between carbon dioxide and agriculture in Ghana: A comparison of VECM and ARDL model. Environmental Science and Pollution Research, 23(11), 10968-10982. https://doi.org/10.1007/s11356-016-6252-X ASUMADU-SARKODIE, S., \& OWUSU, P. A. (2017). The causal nexus between carbon dioxide emissions and agricultural ecosystem - an econometric approach. Environmental Science and Pollution Research, 24(2), 1608-1618. https://doi.org/10.1007/s11356-016-7908-2

ASUMADU-SARKODIE, S. \& OWUSU, P.A. (2016). Carbon dioxide emissions, GDP, energy use, and population growth: a multivariate and causality analysis for Ghana, 1971-2013. Environmental Science and Pollution Research. 23,13508-13520. DOI: https://doi.org/10.1007/s11356-016-6511-x.

AYE, G. C. \& EDOJA, P. E. (2017). Effect of economic growth on $\mathrm{CO} 2$ emission in developing countries:
Evidence from a dynamic panel threshold model. Cogent Economics and Finance, 5, DOI: https://doi.org/10.1080/23322039.2017.1379239

BACCINI, A.G.S.J., GOETZ, S.J., WALKER, W.S., LAPORTE, N.T., SUN, M., SULLA-MENASHE, D., HACKLER, J., BECK, P.S.A., DUBAYAH, R., FRIEDL, M.A. AND SAMANTA, S., (2012). Estimated carbon dioxide emissions from tropical deforestation improved by carbon-density maps. Nature climate change, 2(3), 182-185. DOI: https://doi.org/10.1038/nclimate1354

BALOGH, J. M., \& JÁMBOR, A. (2017). Determinants of $\mathrm{CO} 2$ emission: A global evidence. International Journal of Energy Economics and Policy, 7(5), 217-226. BALSALOBRE-LORENTE, D., SHAHBAZ, M., ROUBAUD, D., \& FARHANI, S. (2018), How economic growth, renewable electricity and natural resources contribute to $\mathrm{CO} 2$ emissions? Energy Policy, 113, 356367. DOI: https://doi.org/10.1016/j.enpol.2017.10.050

BEHERA, B., \& VISHNU, R (2011). Analysing the impact of anthropogenic factors on the environment in India. Environ Nat Resources Res 1: 117-129.

BOSUPENG, M. (2016). The effect of exports on carbon dioxide emissions: policy implications. International Journal of Management and Economics, 51, 20-32. DOI: https://doi.org/10.1515/ijme-2016-0017

BURTON, E. (2000). The compact city: just or just compact? A preliminary analysis. Urban Stud. 37, 19692001.

CODJOE, S. N. A., \& DZANKU, F. M. (2009). Longterm determinants of deforestation in Ghana: The role of structural adjustment policies. African Development Review, 21(3), 558-588.

CHAN, S., JIN, H., \& LU, Y. (2019). Impact of urbanization on $\mathrm{CO}_{2}$ emissions and energy consumption structure: A panel data analysis for Chinese prefecturelevel cities. Structural Change and Economic Dynamics, 49, 107-119. DOI: https://doi.org/10.1016/j.strueco.2018.08.009

CUARESMA, J. C., DANYLO, O., FRITZ, S., MCCALLUM, I., OBERSTEINER, M., SEE, L., \& WALSH, B. (2017). Economic Development and Forest Cover: Evidence from Satellite Data. Scientific Reports, 7,40678. DOI: https://doi.org/10.1038/srep40678

DESJARDINS, R. L., WORTH, D. E., VERGÉ, X. P. C., VANDERZAAG, A., JANZEN, H., KROEBEL, R., \& DYER, J. A. (2014). Carbon footprint of agricultural products-a measure of the impact of agricultural production on climate change. In International Conference on Promoting Weather and Climate Information for Agriculture and Food Security, Antalya. DOI: http://www.wamis.org/agm/meetings/teco14/S5Desjardins.pdf

DINDA, S. (2004). Environmental Kuznets curve hypothesis: a survey. Ecological economics, 49(4), 431455. DOI: https://doi.org/10.1016/j.ecolecon.2004.02.011 DOGAN, E., \& OZTURK, I. (2017). The influence of renewable and non-renewable energy consumption and real income on $\mathrm{CO}_{2}$ emissions in the USA: evidence from structural break tests. Environ Sci Pollut Res, 24: 1084610854. DOI: https://doi.org/10.1007/s11356-017-8786-y DICKEY, D.A., \& FULLER, W.A. (1979). Distribution of the estimators for autoregressive time series with a unit 
root. Journal of the American Statistical Association, 74, 427-431. DOI:

https://doi.org/10.1080/01621459.1979.10482531

EL-AASAR, K. M., \& HANAFY, S. A. (2018). Investigating the environmental Kuznets curve hypothesis in Egypt: the role of renewable energy and trade in mitigating GHGs. International Journal of Energy Economics and Policy, 8(3), 177-184.

ELLIOTT, J.R., \& CLEMENT, M.T. (2014). Urbanisation and carbon emissions: A nationwide study of local countervailing effects in the United States. Social Science Quarterly, 95, 795-816. DOI: https://doi.org/10.1111/ssqu.12079

ENGLE, R. F., \& GRANGER, C.W.J. (1987). Cointegration and error correction: representation, estimation, and testing. Econometrica 55, 251-276. DOI: $\underline{10.2307 / 1913236}$

ERICKSON, P. VAN ASSELT, H., KEMP-BENEDICT, E., \& LAZARUS, M. (2013). International trade and global greenhouse gas emissions: Could shifting the location of production bring GHG benefits? Project Report 2013-02, Stockholm Environment Institute, Sweden.

EWERS R. M. (2006). Interaction effects between economic development and forest cover determine deforestation rates. Global Environmental Change, 16, 161-169.

https://doi.org/10.1016/j.gloenvcha.2005.12.001

DOI:

FAO. Food and Agriculture Organization of the United Nations. (2014). Available online: http://www.fao.org/home/en/(accessed on 2 March 2019). FAO. Global Forest Resources Assessments Food and Agriculture Organization of the United Nations. Available online: http://www.fao.org/forest-resourcesassessment/en/ (accessed on 24 April 2019).

FAO. Food and Agriculture Organization (2019) National Aquaculture Sector Overview: Egypt http://www.fao.org/fishery/countrysector/naso_egypt/en (Accessed on August 29, 2019)

FAO (2003) National Aquaculture Sector Overview, Egypt.

http://www.fao.org/fishery/countrysector/naso_egypt/en (Accessed on August 25, 2019)

GALINATO, G. I., \& GALINATO, S. P. (2012). The effects of corruption control, political stability and economic growth on deforestation-induced carbon dioxide emissions. Environment and Development Economics, 17, 67-90. https://doi.org/10.1017/S1355770X11000222

GROSSI G., GOGLIO P., VITALI A., \& WILLIAMS A. G (2019). Livestock and climate change: impact of livestock on climate and mitigation strategies. Animal Frontiers, $\quad 9(1), \quad 69-76 . \quad$ DOI: https://doi.org/doi:10.1093/af/vfy034

GROSSMAN, G. M., \& KRUEGER, A.B., (1995). Economic growth and the environment. Quarterly Journal of Economics, 110, 353-377. DOI: https://doi.org/10.2307/2118443

HALICIOĞLU, F. (2008). An econometric study of $\mathrm{CO}_{2}$ emissions, energy consumption, income and foreign trade in Turkey. Energy Policy, 37, 1156-1164. DOI: 10.1016/j.enpol.2008.11.012.

HARRIS, J.M. (2004), Trade and Environment. Global
Development and Environment Institute, Tufts University. HASSAN, M., (2016). Urbanization and $\mathrm{CO}_{2}$ emission in Bangladesh: The Application of STIRPAT model. A paper presented at the Insearch 2016: 3rd International Integrative Research Conference on Development, Governance and Transformation on the $27 \& 28$ December 2016, at BARD, Comilla, Bangladesh.

IBRAHIEM D.M. (2016): Environmental Kuznets curve: an empirical analysis for carbon dioxide emissions in Egypt. International Journal of Green Economics, 10(2), 136-150

ISMAEL, M., SROUJI, F. \& BOUTABBA, M.A. (2018). Agricultural technologies and carbon emissions: evidence from Jordanian economy. Environmental Science and Pollution Research. DOI: https://doi.org/10.1007/s11356018-1327-5.

KEHO, Y. (2015). An econometric study of the long-run determinants of CO2 emissions in Cote D'Ivoire. Journal of Finance and Economics, 3(2), 11-21. DOI: $\underline{10.12735 / \mathrm{jfe} . v 3 \mathrm{i} 2 \mathrm{p} 11}$

KWAKWA, P. A., ADU, G., \& OSEI-FOSU, A. K. (2018). A time series analysis of fossil fuel consumption in Sub-Saharan Africa: evidence from Ghana, Kenya and South Africa. International Journal of Sustainable Energy Planning and Management, 17: 31-44. DOI: https://doi.org/10.5278/ijsepm.2018.17.4

KWAKWA, P.A, \& ADU, G. (2016). Effects of income, energy consumption, and trade openness on carbon emissions in sub-Saharan Africa. J Energy Dev 41: 86117. DOI: https://www.jstor.org/stable/90005933

KWAKWA, P.A., \& ALHASSAN, H. (2018). The effect of energy and urbanisation on carbon dioxide emission: evidence from Ghana. OPEC Energy Review, 42(4), 301330. DOI: https://doi.org/10.1111/opec.12133

KWAKWA, P.A., ALHASSAN, H., \&ADU, G. (2018). Effect of natural resources extraction on energy consumption and carbon dioxide emission in Ghana. MPRA Paper No. 85401. DOI: https://mpra.ub.unimuenchen.de/85401/

KWAKWA, P.A., ARKU, F.S., \& ABOAGYE, S. (2014). Environmental degradation effect of agricultural and industrial growth in Ghana. J Rural Industrial Dev, 2: 18.

LIDDLE, B. (2001), Free trade and the environmentdevelopment system. Ecological Economics, 39(1), 21-36. DOI: https://doi.org/10.1016/S0921-8009(01)00215-4

LÜTKEPOHL, H. (2010). Variance Decomposition. In: Durlauf S.N., Blume L.E. (eds) Macroeconometrics and Time Series Analysis. The New Palgrave Economics Collection. Palgrave Macmillan, London. DOI: https://doi.org/10.1057/9780230280830_38.

MAHMOOD H., FURQAN M., ALKHATEEB T. T. Y., \& FAWAZ M. M. (2019). Testing the Environmental Kuznets Curve in Egypt: Role of Foreign Investment and Trade. International Journal of Energy Economics and Policy, 2019, 9(2), 225-228. DOI: https://doi.org/10.32479/ijeep.7271

MARTINEZ-ZARZOSO, I., \&MARUOTTI, A. (2011). The impact of urbanization on $\mathrm{CO} 2$ emissions: evidence from developing countries. Ecol. Econ. 70, 1344-1353. DOI: https://doi.org/10.1016/j.ecolecon.2011.02.009 MCGRANAHAN, G., JACOBI, P., SONGSORE, J., 
SURJADI, C., \& KJELLEN, M. (2001). The citizens at risk, from urban sanitation to sustainable cities. Earthscan, London.

MCGEE, J.A, \& YORK, R. (2018) Asymmetric relationship of urbanization and $\mathrm{CO} 2$ emissions in less developed countries. PLoS ONE 13(12): e0208388. DOI: https://doi.org/10.1371/journal.pone.0208388.

MORAN, D., \& WALL, E. (2011). Livestock production and greenhouse gas emissions: Defining the problem and specifying solutions. Animal Frontiers, 1(1), 19-25. DOI: https://doi.org/doi:10.2527/af.2011-0012

MONGABAY (n.d). Egypt Forest Information and Data. https://rainforests.mongabay.com/deforestation/2000/Egy pt.htm (Accessed on July 4 2019)

MARASENI, T. N., \& COCKFIELD, G. (2011). Crops, cows or timber? Including carbon values in land use choices. Agriculture, ecosystems \& environment, 140(12), 280-288.

DOI:

https://doi.org/10.1016/j.agee.2010.12.015

MOL, A.P.J., \& SPAARGAREN, G., (2000). Ecological modernization theory in debate: a review. Environ. Polit. 9, $17-49$.

DOI:

https://doi.org/10.1080/09644010008414511

NASSANI, A. A., ALDAKHIL, A. M., ABRO, M. M. Q., \& ZAMAN, K. (2017). Environmental Kuznets curve among BRICS countries: spot lightening finance, transport, energy and growth factors. Journal of Cleaner Production, 154, 474-487. DOI: https://doi.org/10.1016/j.jclepro.2017.04.025

NEUMAYER, E. (2004). National Carbon Dioxide Emissions, Geography Matters, Area, 36(1), 33-40. DOI: https://doi.org/10.1111/j.0004-0894.2004.00317.x

OMRI, A. (2013). CO2 emissions, energy consumption and economic growth nexus in MENA countries: Evidence from simultaneous equations models. Energy economics, 40, 657-664. DOI: https://doi.org/10.1016/j.eneco.2013.09.003

ONAFOWORA, O., \& OWOYE, O.(2014). Bounds testing approach to analysis of the environment Kuznets curve hypothesis. Energy Econ 44: 47-62. https://doi.org/10.1016/j.eneco.2014.03.025

OWOYE, O., \& ONAFOWORA, O. A. (2013). Carbon Emissions and Income Trajectory in Eight Heterogeneous Countries: The Role of Trade Openness, Energy Consumption and Population Dynamics. Journal of Global Economy, 9(2), 87- 125

OWUSU, P. A., \& ASUMADU-SARKODIE, S. (2017). Is there a causal effect between agricultural production and carbon dioxide emissions in Ghana? Environmental Engineering Research, 22(1), 4054. DOI: https://doi.org/10.4491/eer.2016.092.

PAL, D., \& MITRA, S.K. (2017). The environmental Kuznets curve for carbon dioxide in India and China: Growth and pollution at crossroad. J Policy Model 39: 371-385.

https://doi.org/10.1016/j.jpolmod.2017.03.005

PANAYOTOU, T., (1997). Demystifying the environmental Kuznets curve: turning a black box into a policy tool. Environment and Development Economics, 2, 4 , $465-484$. DOI: https://doi.org/10.1017/S1355770X97000259 PANHWAR, F. (2004). Organic farming in Pakistan.
Retrieved

from. http://www.cityfarmer.org/pakistanOrgFarming.html\#org prod .

PARAJULI, R., JOSHI, O., \& MARASENI, T. (2019). Incorporating forests, agriculture, and energy consumption in the framework of the Environmental Kuznets Curve: a dynamic panel data approach. Sustainability, $11(9), \quad 2688 . \quad$ DOI: https://doi.org/10.3390/su11092688

PHILLIPS, P.C.B., \& HANSEN, B.E. (1990). Statistical inference in instrumental variables regression with $\mathrm{I}(1)$ processes. Rev Econ Stud, 57, 99-125. DOI: https://doi.org/10.2307/2297545

PHILLIPS, P. C. B., \& OULIARIS, S. (1990). Asymptotic Properties of Residual Based Tests forCointegration. Econometrica 58, 165-193. DOI: 10.2307/2938339

PHILLIPS, P.C.B., \& PERRON, P. (1988). Testing for a unit root in time series regressions. Biometrika 75, 335346. DOI: https://doi.org/10.1093/biomet/75.2.335

PELLERIN, S., BAMIĖRE L, ANGER D, BÉLINE F, BENOÎTM, BUTAULT JP, CHENU C, COLNENNEDAVID C, DE CARA S, DELAME N, DOREAU M, DUPRAZ P, FAVERDIN P, GARCIA-LAUNAY F, HASSOUNA M, HÉNAULT C, JEUFFROY MH, KLUMPP K, METAY A, MORAN D, RECOUS S, SAMSON E, SAVINI I, PARDON L. (2013). Quelle contribution de l'agriculturefrançaise à la réduction des émissions de gaz à effet de serre? Potentield'atténuation et coût de dix actions techniques. Synthèse du rapport d'étude, INRA (France), p. 92

POUMANYVONG, P., \& KANEKO, S. (2010). Does urbanization lead to less energy use and lower $\mathrm{CO} 2$ emissions? A cross-country analysis. Ecol Econ 70, 434 444. DOI: https://doi.org/10.1016/j.ecolecon.2010.09.029 PIÉ, L., FABREGAT-AIBAR, L., \& SAEZ, M. (2018). The Influence of Imports and Exports on the Evolution of Greenhouse Gas Emissions: The Case for the European Union. Energies, 11, 1644; DOI: https://doi.org/10.3390/en11071644

REHMAN, A., OZTURK, I., \& ZHANG, D. (2019). The causal connection between $\mathrm{CO}_{2}$ emissions and agricultural productivity in Pakistan: Empirical evidence from an autoregressive distributed lag bounds testing approach. Applied Science, 9, 1-16. DOI: https://doi.org/10.3390/app9081692

ROBB, D. H., MACLEOD, M., HASAN, M. R., \& SOTO, D. (2017). Greenhouse gas emissions from aquaculture: a life cycle assessment of three asian systems. FAO Fisheries and Aquaculture Technical Paper, (609). DOI: http://www.fao.org/3/a-i7558e.pdf Accessed on August $\underline{24}, 2019$

SADORSKY, P. (2014). The effect of urbanization on $\mathrm{CO} 2$ emissions in emerging economies. Energy Economics, 41, 147-153.DOI: https://doi.org/10.1016/j.eneco.2013.11.007

SADORSKY, P. (2011) Financial development and energy consumption in central and eastern European frontier economies. Energy Policy 39: 999-1006. DOI: https://doi.org/10.1016/j.enpol.2010.11.034

SHAHBAZ, M., LEAN, H.H., \& SHABBIR, M.S. (2012). Environmental Kuznets curve hypothesis in Pakistan: cointegration and Granger causality. Renew Sust Energy 
Rev

16:

2947-2953.

https://doi.org/10.1016/j.rser.2012.02.015

SHAHBAZ, M., NASREEN, S., ABBAS, F., \& ANIS, O.(2015). Does foreign direct investment impede environmental quality in high-, middle-, and low-income countries? Energy Econ 51:275-287. DOI: https://doi.org/10.1016/j.eneco.2015.06.014

SHAHBAZ, M., FERRER, R., SHAHZAD, S. J. H., \& HAOUAS, I. (2018). Is the tourism-economic growth nexus time-varying? Bootstrap rolling-window causality analysis for the top 10 tourist destinations. Applied Economics, $\quad 50(24), \quad 2677-2697$. https://doi.org/10.1080/00036846.2017.1406655

SHARMA, S.S. (2011). Determinants of carbon dioxide emissions: empirical evidence from 69 countries. Appl. Energy, $\quad 88, \quad 376-382 . \quad$ DOI: https://doi.org/10.1016/j.apenergy.2010.07.022

SINHA, A. \& SEN, S. (2016). Atmospheric consequences of trade and human development: A case of BRIC countries. AtmosPollut Res 7: 980-989. DOI: https://doi.org/10.1016/j.apr.2016.06.003

SINHA, A., SHAHBAZ, M., \& BALSALOBRE, D. (2017). Exploring the relationship between energy usage segregation and environmental degradation in $\mathrm{N}-11$ countries. J Clean Prod 168: 1217-1229. https://doi.org/10.1016/j.jclepro.2017.09.071

SINHA, A., \& SHAHBAZ, M. (2018) Estimation of Environmental Kuznets Curve for $\mathrm{CO} 2$ emission: Role of renewable energy generation in India. Renew Energy 119: 703-711. https://doi.org/10.1016/j.renene.2017.12.058

SHAHBAZ, M., \& SINHA, A. (2019). Environmental Kuznets curve for $\mathrm{CO} 2$ emissions: a literature survey. Journal of Economic Studies, 46(1), 106-168. DOI: https://doi.org/10.1108/JES-09-2017-0249

SOLIMAN, N. F., \& YACOUT, D. M. (2016). Aquaculture in Egypt: status, constraints and potentials. Aquaculture international, 24(5), 1201-1227. DOI: https://doi.org/10.1007/s10499-016-9989-9

STERN, D.I. (2003). International Society for Ecological Economics. Internet Encyclopaedia of Ecological Economics. The Environmental Kuznets Curve. Department of Economics, Rensselaer Polytechnic Institute, Troy, NY 12180, USA.

STERN, N. (2006). Stern Review: The Economics of Climate Change. HM Treasury. Cambridge University Press, UK.
TIWARI, A. K., SHAHBAZ, M., \& HYE, Q. M. A. (2013). The environmental Kuznets curve and the role of coal consumption in India: cointegration and causality analysis in an open economy. Renewable and Sustainable Energy Reviews, 18, 519-527. DOI: https://doi.org/10.1016/j.rser.2012.10.031

TWEREFOU, D.K., ADUSAH-POKU, F.,\& BEKOE, W. (2016). An empirical examination of the Environmental Kuznets Curve hypothesis for carbon dioxide emissions in Ghana: an ARDL approach. Environmental \& SocioEconomic Studies 4, 4, 1-12. https://doi.org/10.1007/s10499-016-9989-9

VALIN, H., HAVLIK, P., MOSNIER, A., HERRERO, M., SCHMID, E., \& OBERSTEINER, M. (2013). Agricultural productivity and greenhouse gas emissions: trade-offs or synergies between mitigation and food security? Environ Res Lett 8: 1-9. https://doi.org/10.1515/environ-2016-0019

WAHEED, R., CHANG, D., SARWAR, S., \& CHEN, W. (2017). Forest, agriculture, renewable energy and CO2 emissions. Journal of Cleaner Production, DOI: https://doi.org/10.1016/j.jclepro.2017.10.287

WORLD DEVELOPMENT INDICATOR (WDI), 2019. http://databank.worldbank.org/data/reports.aspx?source= world-development-indicators.

WORLDEXGROUP (2018) Cultivating International Food Trade. http://worldexgroup.com/wpcontent/uploads/2018/02/FoodAfrica2018-Brochure.pdf. Accessed on September 2, 2019

ZHANG Y.J., YI, W.C, \& LI, B.W. (2015). The impact of urbanization on carbon emission: empirical evidence in Beijing. Energy Procedia, 75, 2963 - 2968. https://doi.org/10.1016/j.egypro.2015.07.601

ZIVOT, E., \& ANDREWS, D.W.K.(1992). Further evidence on the Great Crash, the Oil-Price Shock, and the Unit-Root Hypothesis. J Bus Econ Stat 10: 251-270. DOI: https://doi.org/10.1198/073500102753410372 